\title{
Does Covid-19 Pandemic Change the Consumer Purchase Behavior Towards Cosmetic Products?
}

Received: August 07, 2021

Accepted: January 15, 2022

*Corresponding author: Mega Farisha, Bussiness School, IPB University, Bogor, Indonesia

E-mail:

farishamega@gmail.com

Additional information is available at the end of the article

\author{
Mega Farisha ${ }^{\left.1^{*}\right)}$, Hartoyo ${ }^{2}$, Arief Safari ${ }^{3}$
}

Abstract: The Covid-19 pandemic has generally affected the cosmetic industry's marketing and sales. Drastic changes happened, and the sales now rely more on online sales. This study aimed to analyze the purchase behavior of facial serum cosmetic products before and during the Covid-19 pandemic. The sampling technique applied purposive sampling. Data analysis used Structural Equation Modelling - Partial Least Squares (SEM-PLS). Data were obtained from 200 respondents in the Jabodetabek area from April to May 2021, but only 163 were included in the analysis. The results show that the conditions before and during the pandemic are significant differences. Before the pandemic, co-creation, communal activation, conversation, halal awareness, and reference groups influenced the purchase behavior. On the other hand, though, reference groups did not affect the purchasing behavior during the pandemic. Therefore, business people in the cosmetics field can focus on co-creation and conversation.

Keywords: cosmetic, covid-19, facial serum, purchase behavior, structural equation modeling - partial least squares (SEM-PLS)

JEL Classification: L0, M31, L67, L11

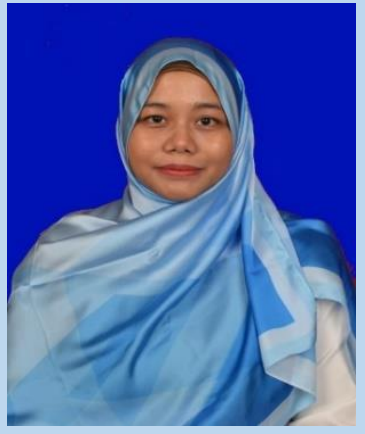

Mega Farisha

\section{ABOUT THE AUTHORS}

Mega Farisha is a student at IPB university's business school, postgraduate class. She has completed her undergraduate studies at Padjadjaran University majoring in economics and development studies in 2010. Currently, she is still listed as an employee of BUMN (PT PLN Persero). She can be reached via farishamega@gmail.com

Hartoyo is a lecturer at IPB business school who serves as chairman of the school senate. Previously served in the Department of Family and Consumer Sciences, Faculty of Human Ecology as department chair. He can be reached via hartoyo@apps.ipb.ac.id

Arief Safari is a lecturer at IPB Business School and the Ahmad Dahlan Institute of Technology and Business. He has worked at PT Sucofindo for 18 years with the last position being president director. In 2017-2020 he became commissioner of BPKN and was selected again for 2020-2023. He can be reached via safari2606@gmail.com

\section{PUBLIC INTEREST STATEMENT}

In a pandemic situation, the communal activation variable does not affect the buying behavior of facial serum. This is because consumers focus on the benefits, prices, and promotional patterns offered by producers so that by switching to online shopping supported by adequate logistical support, consumers are not worried about distribution channels.

In addition, religious beliefs held by the majority of the population, health reasons, and the halal logo increase awareness of the halalness of a product that is consumed.

This includes trust in reference groups because consumers prioritize the basic needs of life over other needs. Consumers limit spending due to a decrease in income so that their purchasing power decreases and they do not buy beyond their needs. In addition, reference groups, especially influencers on social media, do not necessarily influence buying behavior. 


\section{Introduction}

Cosmetics are mandatory tools for women to support their appearance. The classification of cosmetics, when viewed from the benefits for the skin, consists of decorative makeup and skincare products. The buyers of cosmetic products can be high or low involvement purchases. High involvement purchase stands for the condition of purchasing a product based on the usefulness and the risks contained in the product (Schiffman \& Wisenblit, 2019). In a high involvement purchase, the buyer of a cosmetic product is at high risk since it has a direct effect on the skin, and it is said to be a low involvement purchase if the product has an indirect effect or is at a low level of risk. For instance, a facial serum that is not suitable to use will directly impact the face, such as acne, dullness, and others. The serum is an active substance in liquid form that can penetrate the skin to nourish and rejuvenate it.

Consumer product purchases are primarily determined by product knowledge (Sunyoto, 2013). This condition shapes the perception of prospective face serum consumers to determine whether to buy or not. When deciding to buy a facial serum product, prospective consumers need various considerations to get a product that suits their skin type and the desired benefits, so several indicators are needed.

The cosmetic industry continues to grow due to the increasing trend that shows public awareness of cosmetic products. However, the Covid-19 pandemic broke out at the end of December 2019 and became a global pandemic on March 12, 2020. As a result, Indonesia has decided to implement large-scale social restrictions (PSBB) and community activities (PPKM), regulated by the Indonesian government. In essence, when PSBB and PPKM are implemented, workplace restrictions are carried out by implementing Work From Home (WFH), implementing learning from home (SFH) or online mechanisms, implementing social distancing. During the Covid-19 pandemic, the cosmetic industry was also affected. For example, in terms of marketing and sales, experiencing drastic changes that now rely more on online sales. At the beginning of the pandemic, offline cosmetic sales were even closed due to the implementation of the PSBB. This condition complicates the situation because they still have to pay operational costs every month. This situation requires the cosmetic industry to update its marketing strategy by using an online system and expanding into e-commerce. In addition, the cosmetic industry also needs to understand consumer behavior and build loyalty to consumers.

The research that will be conducted at this time is to analyze the buying behavior model by looking at the factors that influence it in terms of the $4 \mathrm{C}$ marketing mix where previous research only focused on the 4P marketing mix and support research related to the influence of the $4 \mathrm{C}$ marketing mix on purchasing behavior (Eganeal, Jiwa, Sitepu, \& Kumar, 2020; Rieg, Scramim, Paola, \& Rugfino, 2018; Mustaqimah, Hartoyo, \& Nurmalina, 2019; Hutauruk, 2020). Furthermore, this study also looks at buying behavior models in the Covid-19 pandemic phenomenon. In addition to the $4 \mathrm{C}$ marketing mix, this study also tries to find the relevance of knowledge in terms of halal cosmetic products, where previous research was only related to general product knowledge (Kandemir, Pirtini, \& Bayraktar, 2019; Chinomona \& Maziriri, 2017). Another variable that was also studied was related to reference groups that influenced buying behavior before and during the Covid-19 pandemic, where previous research only related to reference groups in other conditions (Pandowo \& Tuwo, 2015; Hall \&Tower, 2017; Mican \&Sitar-taut, 2020; Ramadhan \& Simanjuntak, 2018).

\section{Literature Review}

\subsection{Marketing Mix}

A marketing mix combines elements used as a marketing strategy tool. Jerome McCarthy, in 1960 introduced the concept of this marketing mix with the 4P concept, which consists of the product (product), price (pricing), place (distribution location), and promotion (promotion). This concept was developed by Kotler and Armstrong (1997), who stated that the 4P concept is used to achieve marketing goals in the target market by developing an integrated marketing program from a combination of the four elements (4P). 
There has been a shift in purchasing a product, done initially at retail or shops where buyers will purchase products after seeing the product. However, it has shifted to the digital realm, supported by various e-commerce platforms or websites for product sales. This is in line with the idea expressed by Kotler in Marketing 4.0 (moving from traditional to digital), which combines online and offline interactions explaining that in this digitalization era, the concept of the marketing mix has also developed to be more accommodating to customer participation (Kotler, Kartajaya, \& Setiawan, 2017). Therefore, the marketing mix that departs from the 4P must be redefined into $4 C$, which is allegedly more relevant in the digitalization era.

Table 1. Marketing mix 4P and $4 \mathrm{C}$

\begin{tabular}{lr}
\hline Marketing Mix 4P & Marketing Mix 4C \\
\hline Product & Co-creation \\
Price & Currency \\
Place & Communal activation \\
Promotion & Conversation \\
\hline
\end{tabular}

1. Co-creation (creating together)

This condition reflects the determination of strategies in developing new products that involve customers.

2. Currency

Pricing is also developing in the digital era, which moves from standard pricing to a dynamic direction. By using dynamic pricing, the company gets optimal profit by charging different fees to each customer according to purchasing patterns, distance to store locations, and other aspects of customer profiles.

3. Communal activation

Communal activities become a transition from the concept of distribution channels. An essential factor in how customers decide to buy in a digital environment is speed or time. The purpose of this communal activity is that the company only provides a platform while the products being traded belong to the surrounding customers.

4. Conversation

The promotion concept is also developing towards two-way communication, which previously was only one-way. The incessant social media makes customers able to respond to something informed. It also allows customers to interact with fellow customers.

In previous studies on the influence of the marketing mix on purchasing behavior at hotels in Surabaya, the marketing mix influences consumers in purchasing decisions or choosing hotel rooms in Surabaya (Eganeal, Jiwa, Sitepu, \& Kumar, 2020). Another study in Pakistan that $4 \mathrm{C}$ elements in the marketing mix applied by companies will make consumers more confident and support their products (Kandemir, Pirtini, \& Bayraktar, 2019). Research on the $4 \mathrm{C}$ marketing mix directly influences purchasing decisions and is indirectly shown by consumer behavior (Hutauruk, 2020). Other studies have also revealed that maintaining many customers requires several things that stand out, such as excellent and unique quality and attractive promotions. In addition, it is also influenced by price, product brand, and style or type of product (Rieg, Scramim, Paola, \& Rugfino, 2018).

Purchase decisions are strongly influenced by product packaging, both in terms of the appearance of the packaging and the writing on the packaging (Salem, 2018). Packaging is a form of communication between brands and consumers (Kotler and Armstrong, 2008). Manufacture of product containers that aim to protect products and assist product sales.

The promotional element in the marketing mix is no less critical in considering purchasing decisions and comparing discounts and promotional programs, where 
discount programs are preferred by consumers (Gong, Hou, Zhang, \& Tian, 2018). Furthermore, the $4 \mathrm{C}$ marketing mix (co-creation, currency, communal activation, and conversation) simultaneously affects the consumer journey (Krisnawati, 2019). Therefore, to find out consumer buying behavior, it is very relevant to use the $4 \mathrm{C}$ marketing mix, considering that this point can represent the state of the consumer. The research that will be carried out is indeed based on the variables used in previous studies, but what distinguishes it from other research is conducting research related to facial serum in conditions before and during the covid-19 pandemic.

\subsection{Halal Awareness}

Halal awareness is customers' knowledge about products or services used or consumed, including halal or haram. To make it easier for customers to know or evaluate a product or service included in the halal category, there will usually be a halal logo or a halal certificate in a product or service. The theory of halal awareness is rooted in the Theory of Planned Behavior (Ajzen, 1991; Aziz \& Chok, 2013). According to TPB, three central components influence human behavior: attitudes, subjective norms, and control over behavior. Halal awareness is more representative of the attitude component that begins with the belief that a product is halal to lead to an attitude to buy. Therefore, the habits of Muslim consumers make them aware, and care of the halalness of a product used so as not to cause anxiety when using it.

Along with the development of knowledge and technology, non-Muslims also feel concerned about the halal condition because this can show that the product is made of good and non-destructive ingredients (Haque, Sarwar, Yasmin, Tarofder, \& Hossain, 2015; Annabi \& Ibidapo-Obe, 2017). Thus, halal cosmetics are defined as beauty and skincare products starting from the ingredients used, the manufacturing process, storage, packaging, and shipping according to Islamic provisions (natural ingredients come from clean sources, no animal testing). The current trend is that Muslim consumers do not only use halal cosmetics; non-muslim consumers also choose this product, not because they are obedient to Islam, but because they are aware of the environment. This can be seen by the willingness of non-Muslim consumers to pay more for halal cosmetic products (Elasrag, 2016).

Halal cosmetic products, quality, and quality significantly influence purchasing decisions (Abdulrani, Sarojani, Zurinah, \& Nurita, 2019). Other studies have also found that awareness of halal products and knowledge of halal products influence a person's purchase intention (Nurhayati \& Hendar, 2019).

Awareness of the existence of halal products in Indonesia is driven by the highest index of Islamic religious belief, and the importance of halal products is in the third position after related to religion, beliefs, and health. Halal awareness includes Muslims, but non-Muslims also have a positive perspective on this concept. This concept is considered reasonable by Muslim majority countries and has penetrated countries with Islamic minorities (Kurniawati \& Savitri, 2019). In addition, non-Muslim adherents, whether in Muslim-majority countries or not, consider the concept of halal awareness as a positive thing; this is related to the quality of the product to be delivered security and animal welfare (Rezai, Mohamed, \& Shamsudin, 2012; Ayyub, 2015).

\subsection{Reference Group}

Reference groups have a direct relationship (face to face) or indirect influence on a person's behavior (Kotler \& Keller, 2008). Alternatively, in simpler terms, a reference group is an individual or group that significantly influences a person's behavior. Within the scope of marketing, the reference group serves as a reference in making purchasing and consumption decisions. There are three types of reference groups (Sumarwan, 2010): 
1. Formal and informal groups

Formal groups have a written organizational structure and officially registered membership-for example, trade unions, political parties, universities, and companies. Meanwhile, informal groups do not have a written and official organizational structure, and the nature of their membership is not recorded. This group is small and interacts closely and face-to-face intensively and regularly. Examples are fitness gymnastics groups, social gathering groups, and neighborhood groups.

\section{Primary and secondary groups}

The primary group is a group with a limited number of memberships, the interaction among members is carried out directly face to face and has emotional bonds between members. In addition, members of this group have the same values, attitudes, and behavior-for example, family and kinship. In comparison, a secondary group is a group that has looser ties than the primary group-for example, professional associations, alumni associations, social gathering groups, sports groups.

\section{Aspiration and dissociation groups}

Aspiration groups show a desire to follow the norms, values, and behaviors of other people who are their reference group. Members of this group try to make associations with people who are their references and behave and behave in the same way as their references. For example, young people like to dress with South Korean fashion mecca as aspirations and South Korean fashion as a reference. While the dissociation group is a person or group of people who try to avoid association with the reference group. For example, one political party shows the order in demonstrating, in contrast to most political parties. These orderly political parties are called dissociative groups.

Research related to reference groups illustrates the significant influence of reference groups on customer purchase intentions in using wedding organizer services. Most respondents agreed to find friends or experts and experienced choosing a wedding organizer. Information from friends about the strength and quality of wedding organizer services can increase customer interest in using wedding organizer services (Pandowo \& Tuwo, 2015). In addition, in the internet era, before consumers decide to buy an item, what they do is search for product-related content, ask for social validation, and browse social media for additional information (Hall \& Tower, 2017). Other studies also emphasize that online purchasing decisions will be influenced mainly by trust, reviews from experts, customer opinions on trusted sources (Mican \& Sitar-Taut, 2020). Therefore, promotions and reference groups significantly affect buying behavior (Ramadhan \& Simanjuntak, 2018).

\section{Conceptual Framework}

The research framework in this study is built based on previous relevant empirical studies, it is suspected that the $4 \mathrm{C}$ marketing mix, halal awareness, and reference groups have an effect on purchasing behavior, and an analysis of the external environment is carried out to analyze the critical success factors that can provide direction for business actors in achieving their goals and can support the improvement of the company's strategy following the following hypotheses and research framework presented in Figure 1. 


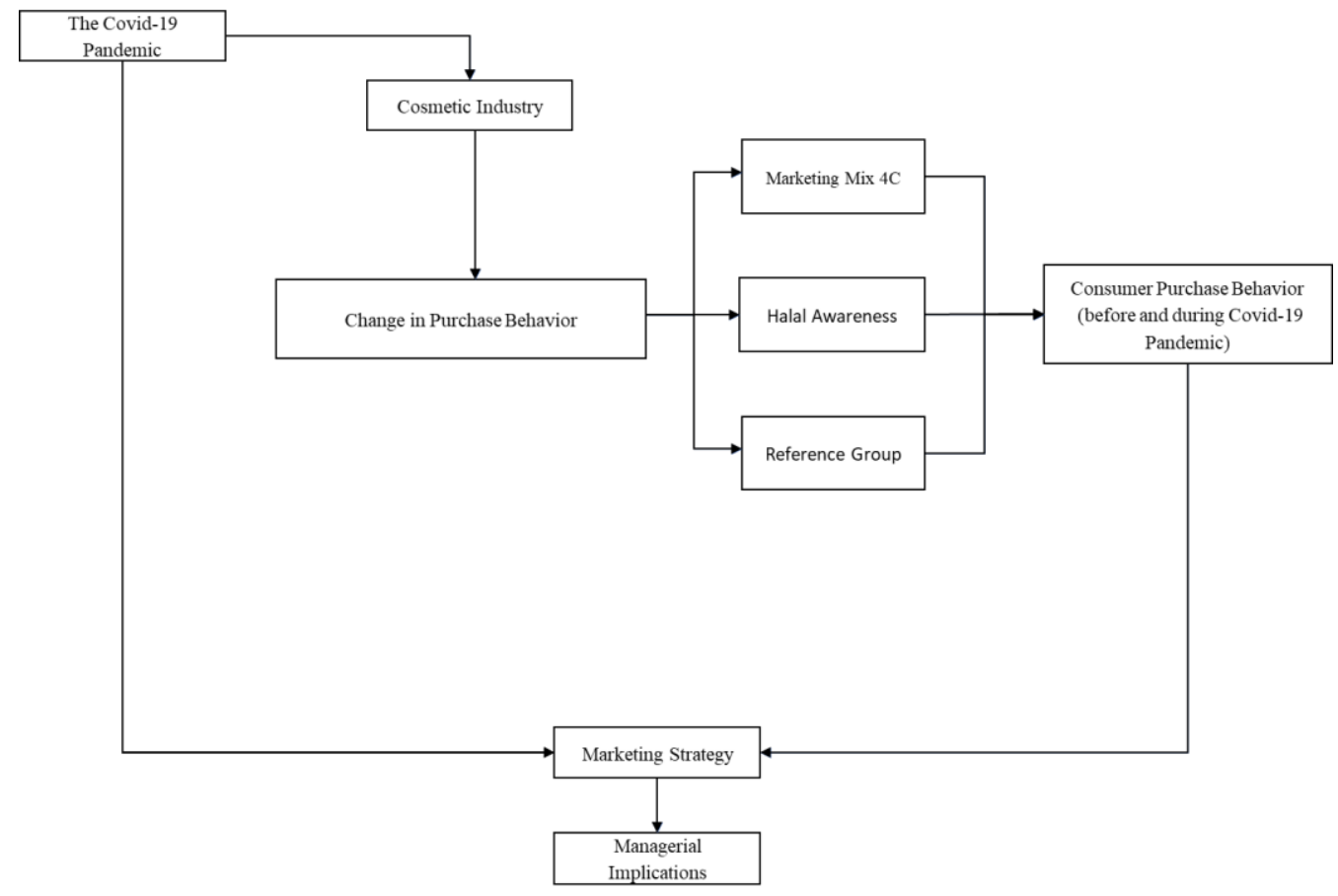

Figure 1. Conceptual framework

Research hypotheses:

H1: Co-creation significantly affect purchase behavior

$\mathrm{H} 2$ : Currency significantly affect purchase behavior

H3: Communal activation significantly affect purchase behavior

H4: Conversation significantly affect purchase behavior

H5: Halal awareness significantly affect purchase behavior

H6: Reference groups significantly affect purchase behavior

\section{Methods}

\subsection{Participants}

The study used purposive sampling to take samples that meet the criteria, namely women aged 15-64 years old living in the Jabodetabek area who purchased and used the local facial serum for skincare from March 1, 2020, to February 28, 2021. The total targeted respondents were 163 respondents using the google form. SEM-PLS model was used in data analysis.

\subsection{Measurement}

Source of data in the form of primary data. Primary data is obtained from respondents' responses to online questionnaires that use technical assistance in the form of online questionnaires because it is not possible to collect data directly to meet with prospective respondents by asking several parts of the question, including open-ended questions covering the identity of the respondent, followed by semiopen questions covering economic status respondents, and closed-ended questions related to the variables in question to respondents. Closed questions will be made using a five-point Likert scale, with the condition that point 1 indicates a strongly disagree attitude, point 5 indicates a strongly agree attitude towards the questions on each indicator. Respondents will also be asked questions regarding the use of facial serum products before and during the Covid-19 pandemic to identify changes in consumer purchase behavior. This study uses the SEM-PLS model in data processing. Table 2 shows the operational definition of the variables. 
Table 2. Operationalization of variables

\begin{tabular}{|c|c|c|c|}
\hline Exogenous Variables & Definition & Symbol & Indicator \\
\hline Co-creation & $\begin{array}{l}\text { Determination of strategy } \\
\text { in developing new products } \\
\text { that involve customers in } \\
\text { ideas that can improve } \\
\text { product development and } \\
\text { enable customers to adjust } \\
\text { according to their wishes. } \\
\text { (Kotler, Kartajaya, \& } \\
\text { Setiawan 2017) }\end{array}$ & $\begin{array}{l}\mathrm{X} 1.1 \\
\mathrm{X} 1.2 \\
\mathrm{X} 1.3 \\
\mathrm{X} 1.4 \\
\mathrm{X} 1.5\end{array}$ & $\begin{array}{l}\text { Identify consumer } \\
\text { behavior in buying } \\
\text { Dialog } \\
\text { Access } \\
\text { Risk assessment } \\
\text { Transparency } \\
\text { (Kotler, Kartajaya, \& } \\
\text { Setiawan, 2017) }\end{array}$ \\
\hline Currency & $\begin{array}{l}\text { Dynamic pricing ensures } \\
\text { optimal profit by charging } \\
\text { different fees to each } \\
\text { customer according to the } \\
\text { history of purchasing } \\
\text { patterns, distance to store } \\
\text { locations, and other } \\
\text { aspects of customer } \\
\text { profiles. } \\
\text { Kartajaya, \& Setiawan } \\
\text { 2017) }\end{array}$ & $\begin{array}{r}X 2.1 \\
\times 2.2\end{array}$ & $\begin{array}{l}\text { Product price based on } \\
\text { market demand } \\
\text { Customers can estimate } \\
\text { the price that should be } \\
\text { Product prices according } \\
\text { to customer wishes } \\
\text { (Kotler, Kartajaya, \& } \\
\text { Setiawan, 2017) }\end{array}$ \\
\hline Communal Activation & $\begin{array}{l}\text { Products that are } \\
\text { distributed both offline \& } \\
\text { online and feel their } \\
\text { presence in a community } \\
\text { provide benefits. The end } \\
\text { goal is customer loyalty } \\
\text { (Kotler, Kartajaya, \& } \\
\text { Setiawan 2017) }\end{array}$ & $\mathrm{X} 3.1$ & $\begin{array}{l}\text { Products are distributed } \\
\text { through the community } \\
\text { offline \& online } \\
\text { Collaborate with various } \\
\text { communities (Kotler, } \\
\text { Kartajaya, \& Setiawan, } \\
\text { 2017) }\end{array}$ \\
\hline Conversation & 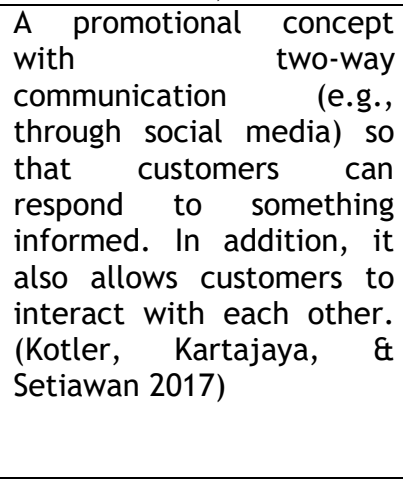 & $\begin{array}{r}X 4.1 \\
\times 4.2\end{array}$ & $\begin{array}{l}\text { There is a communication } \\
\text { from the product with } \\
\text { the customer } \\
\text { The product informs you } \\
\text { about the latest } \\
\text { information about the } \\
\text { product (offline \& online) } \\
\text { Conduct events to } \\
\text { expand communication } \\
\text { with customers } \\
\text { Communication intensity } \\
\text { (Kotler, Kartajaya, \& } \\
\text { Setiawan, 2017) }\end{array}$ \\
\hline Halal Awareness & $\begin{array}{l}\text { Customers' awareness or } \\
\text { knowledge regarding the } \\
\text { products used or consumed } \\
\text { are classified as halal or } \\
\text { haram (Aziz \& Chok, 2013). }\end{array}$ & $\begin{array}{r}X 5.1 \\
\times 5.2 \\
\times 5.3 \\
\times 5.4\end{array}$ & $\begin{array}{l}\text { Knowing the meaning of } \\
\text { halal } \\
\text { Halal is essential for } \\
\text { cosmetic products } \\
\text { Understand the concept } \\
\text { of halalan toyiban } \\
\text { Choose cosmetic } \\
\text { products that are halal } \\
\text { (Setyaningsih \& } \\
\text { Marwansyah, 2019) }\end{array}$ \\
\hline Reference Group & $\begin{array}{l}\text { All groups that have a } \\
\text { direct (face-to-face) or } \\
\text { indirect influence on a } \\
\text { person's behavior or are an } \\
\text { individual or group of } \\
\text { people who significantly } \\
\text { influence a person's } \\
\text { behavior (Kotler \& Keller } \\
\text { 2008; Sumarwan 2010) }\end{array}$ & $\mathrm{X6.1}$ & $\begin{array}{l}\text { Interest in the product } \\
\text { from the story of friends } \\
\text { or relatives } \\
\text { Intense advertisements } \\
\text { in print, electronic and } \\
\text { social media } \\
\text { Product trend effect } \\
\text { Effendi (2019) }\end{array}$ \\
\hline Purchase Behavior & $\begin{array}{l}\text { The condition of how } \\
\text { individuals, groups, and } \\
\text { organizations select, buy, } \\
\text { use, and dispose of goods } \\
\text { that satisfy their needs. }\end{array}$ & $\begin{array}{l}\text { Y1 } \\
\text { Y2 } \\
\text { Y3 } \\
\text { Y4 } \\
\text { Y5 }\end{array}$ & $\begin{array}{l}\text { Marketing stimulation } \\
\text { Other stimulation } \\
\text { Buyer characteristics } \\
\text { Buying decision process } \\
\text { Purchase decision } \\
\text { Kotler \& Keller (2008) }\end{array}$ \\
\hline
\end{tabular}


The research model design is presented in Figure 2, which explains that six independent variables influence the buying behavior of cosmetic products, namely co-creation, currency, communal activation, conversation, halal awareness, and reference group

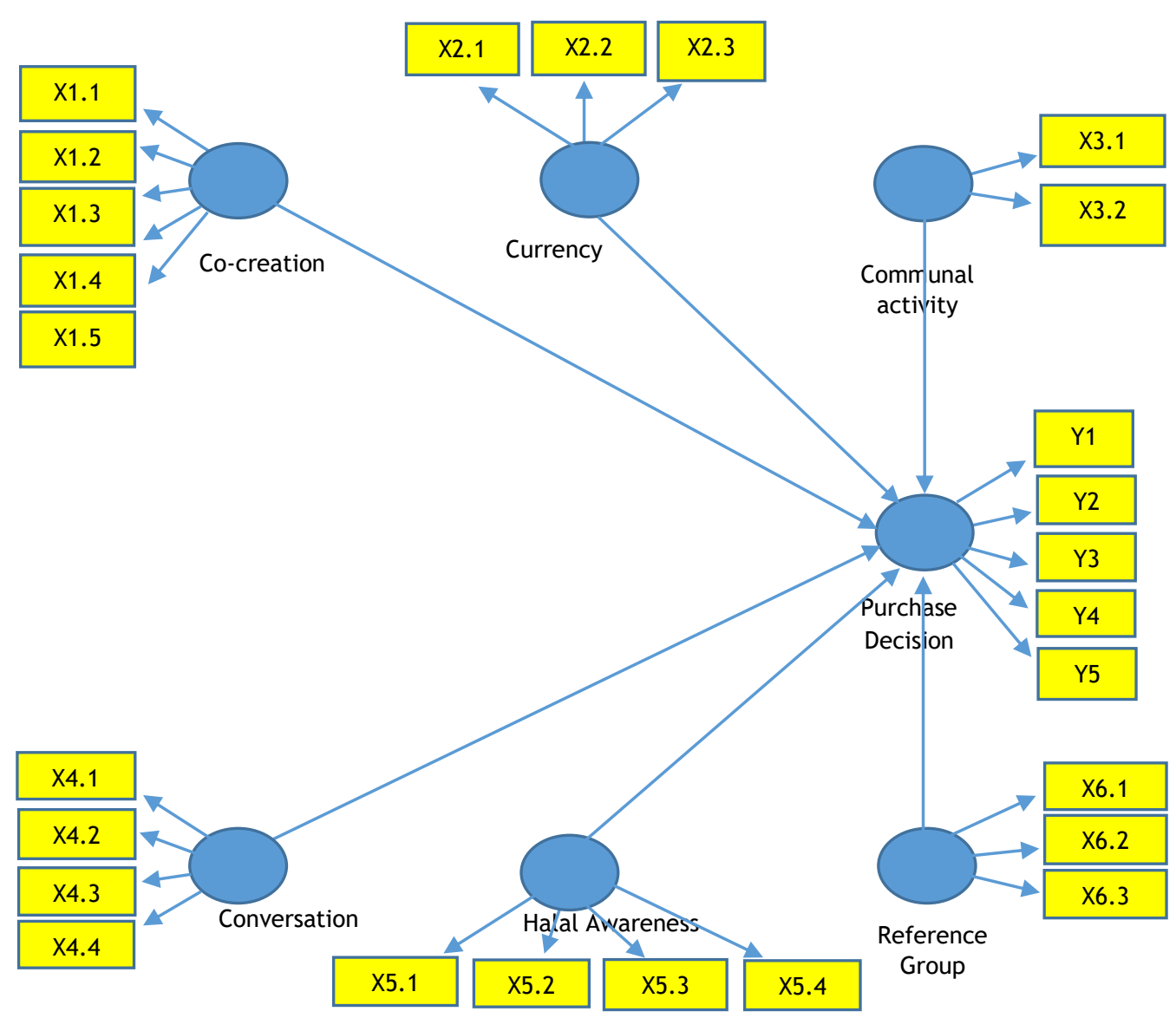

Figure 2. SEM-PLS Model

\subsection{Analysis}

In this study, sampling was non-probability sampling with purposive sampling technique, by taking samples according to predetermined criteria, in research using SEM-PLS. Based on the ten times rule of thumb, the recommended sample size is 5 to 10 times the indicators. There are 26 indicators with 32 parameters in this study, so a sample of 160 to 320 respondents is needed. The number of respondents to be taken is 163 to obtain more precise data.

Measurement of the outer model aims to ensure the instrument in the questionnaire is valid, meaning that it can explain something to be measured based on the following provisions in Table 3.

Table 3. Outer Model Criteria

\begin{tabular}{lrr}
\hline Test & Parameter & Rule of thumb \\
\hline Validity & Loading factor (outer loading) & $>0.5$ \\
\cline { 2 - 3 } & Average Variance Extracted (AVE) & $>0.5$ \\
\hline Reliability & Cronbach Alpha & $>0.6$ \\
\cline { 2 - 3 } & Composite Reliability & $>0.6-0.7$ \\
\hline
\end{tabular}


A validity test is a test to see whether the questionnaire used is good or not. This is done by:

- Convergent Validity

In testing convergent validity, using the loading factor value. An indicator is declared to have convergent validity if the loading factor of each indicator is more than 0.5 . If there is an indicator with a loading factor of less than 0.5 , it must be removed.

- Discriminant Validity

The discriminant validity test it is using the cross-loading value. An indicator is included in the discriminant validity category, that is, if the value of the crossloading indicator on the variable is the most immense compared to other variables. In addition, the discriminant validity test can also be carried out by comparing the average variance extracted (AVE) value of each variable that is greater than the correlations that occur (more than 0.5).

The reliability test determines the questionnaire data's accuracy, consistency, and accuracy. The steps taken are as follows:

- Composite Reliability

Performing a composite reliability test aims to test the reliability value of indicators on a variable. A variable is declared to meet composite reliability if its value is more than 0.7 .

Measurement of the inner model, namely the structural model analysis, ensures that the structural model formed is accurate, following the following guidelines in Table 4.

Table 4. Inner Model Criteria

\begin{tabular}{|c|c|}
\hline Criteria & Rule of thumbs \\
\hline \multirow[t]{2}{*}{ R-Square } & $\begin{array}{l}\geq 0.67, \geq 0.33, \text { dan } \geq 0.19 \text { shows a strong, moderate and weak model } \\
\text { (chin version) }\end{array}$ \\
\hline & $\begin{array}{l}\geq 0.75, \geq 0.50 \text {, dan } \geq 0.25 \text { shows a strong, moderate and weak model } \\
\text { (Hair version) }\end{array}$ \\
\hline $\begin{array}{l}\text { Significance } \\
\text { (two-tailed) }\end{array}$ & $\begin{array}{l}\text { t-value } 1.65 \text { (significant level }=10 \%) \\
\text { t-value } 1.96 \text { (significant level }=5 \%) \\
\text { t-value } 2.58 \text { (significant level }=1 \%)\end{array}$ \\
\hline
\end{tabular}

This evaluation was conducted to show how strong the influence of the independent variable is on the dependent variable. This test can be seen from the R-square value above 0.75 , which is categorized as vital (substantial), the value of 0.5 to 0.75 is categorized as moderate (moderate), and the value of 0.25 to 0.5 is categorized as weak (Hair 2006). If the greater the value of the path coefficient on an independent variable to the dependent variable, the stronger the influence between the independent variables on the dependent variable.

Invalidating the overall model, the Goodness-of-fit (GOF) index test was used, which was introduced by Tenenhaus et al. (2004), better known as the GOF index. This index was developed to evaluate measurement models and structural models, and besides that, it also provides a simple measurement for the overall prediction of the model (Gozhali, 2012). The following formula shows the goodness of fit assessment:

$\mathrm{GoF}=\left((\mathrm{Com}) \times\left(R^{2}\right)\right)$

Where:

Striped com $=$ average communalities

$R^{2}=$ model mean $R^{2}$ 
The GOF value is between 0 to 1 , with the recommended communality value of 0.50 , then with the interpretation of the value 0.10 is included in the criteria for a trim GOF level, 0.25 is a medium GOF value, and more than 0.36 enters a significant GOF value condition (Cohen, 1988). If the GoF value has been found, it indicates that the value is the magnitude of the diversity of the research data that the research model can explain, and other factors outside the research model explain the rest.

Perform hypothesis testing based on the results of the data output obtained. This is done to answer the hypotheses that have been previously set. Hypothesis testing compares the value of $\mathrm{t}$-value with $\mathrm{t}$-table $(\mathrm{t}$-table significant 5 percent $=1.96)$. The hypothesis will be accepted if the value of the $t$-value is greater than the $t$-table ( $t$ value $>1.96$ ).

\section{Findings}

\subsection{Respondent Characteristics}

Based on the study results, 163 respondents, it is known that respondents with an age range of $31-40$ years are the most obtained respondents (56\%), and 151 people are predominantly Muslim. The dominant domiciles in this study were Jakarta and Bogor, which were 33 percent. The ethnicity of the respondents is very diverse, dominated by Javanese and Sundanese at 33 percent ( 54 people) and 26 percent ( 43 people). Based on the level of education, the respondents involved in this study were 69 percent Diploma III and Strata 1 graduates. This level of education is essential to know because this level is one of the factors that determine the decision-making process and consumption patterns (Sumarwan, 2010). Most of the professional respondents' are BUMN and private sector employees, 28 percent and 25 percent, respectively. The income level of respondents is very diverse and is dominated by the range of Rp. 5.000 .000 to Rp. 10.000 .000 , which is 33 percent, while categories above Rp dominate the level of expenditure. 5.000 .000 , which is 51 percent. According to respondents who have filled out the questionnaire, 67 percent of respondents stated that this pandemic had no effect on income, and 33 percent stated otherwise.

\subsection{Measurement Model Fit Before Pandemic}

This test is carried out by testing the validity and reliability of the outer model so that it has the accuracy and reliability of the questionnaire data used in the study. The analysis of the outer model reflects the relationship between latent variables and their indicators. The value that relates the latent variable to the indicator is called the loading factor, which tests the validity.

Figure 3 shows the measurement model after going through several iterations. This condition evaluates the outer model with indicator qualifications with a loading factor of less than 0.5; the model must be recalculated so that the loading factor of all indicators is more than 0.5. this is a convergent criterion of a latent variable (Ghozali, 2008). In addition, a model is said to have good validity if all values of latent variables and their indicators have an AVE value of more than 0.5. the measurement model must also meet the requirements of reliability and discriminant validity. 


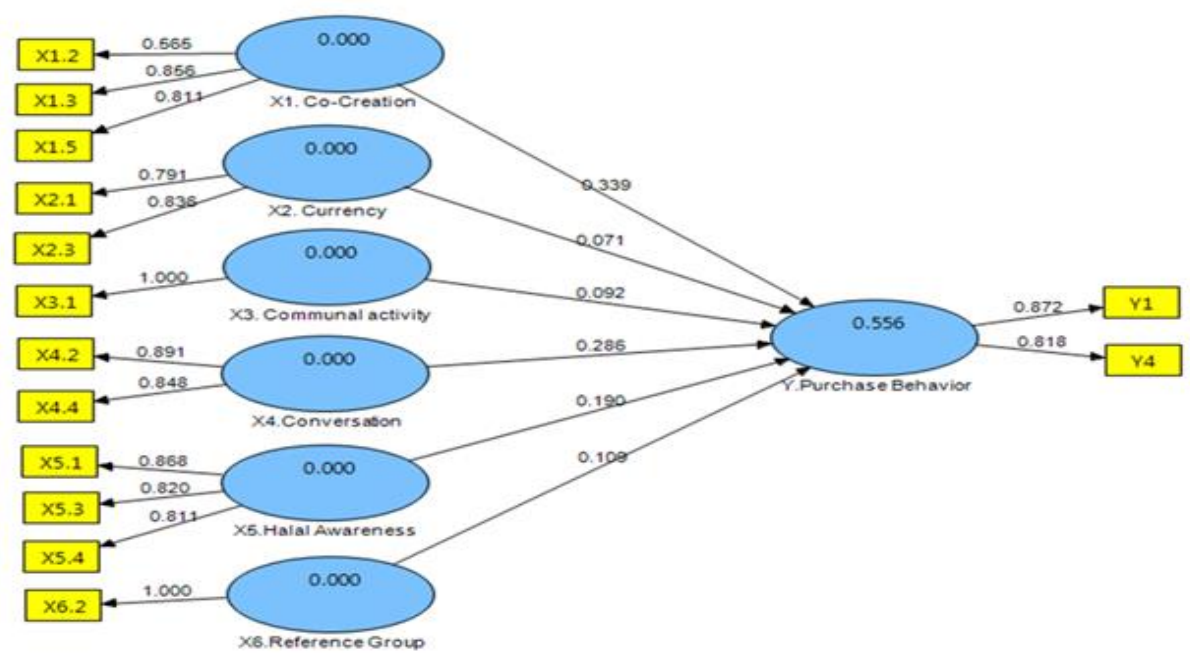

Figure 3. Loading factor before the pandemic

Table 5 shows that the AVE value of all latent variables is more than 0.5 to meet the requirements of convergent validity in the PLS model. This condition occurs after several iterations have been carried out, so it can be ascertained that the latent variables contained in Table 5 are good and valid.

Table 5. Average Variance Extracted (AVE) and Composite Reliability

\begin{tabular}{lcc}
\hline & AVE & Composite Reliability \\
\hline X1. Co-Creation & 0.569 & 0.794 \\
X2. Currency & 0.662 & 0.797 \\
X3. Communal activity & 1.000 & 1.000 \\
X4. Conversation & 0.756 & 0.861 \\
X5. Halal Awareness & 0.694 & 0.872 \\
X6. Reference Group & 1.000 & 1.000 \\
Y.Purchase Behavior & 0.714 & 0.833 \\
\hline
\end{tabular}

Table 5 also shows the composite reliability value of each latent variable of more than 0.7. it means that each latent variable has good, accurate, and consistent reliability. Another way to ensure the validity of the test is with a cross-loading value that is greater than the other latent variables.

Table 6 shows that the overall value of cross-loading between indicators on latent variables is greater than the value of cross-loading for other latent variables so that this model has passed the validity test, which means that the questionnaire used in the study is good and valid.

Table 6. Cross loading value

\begin{tabular}{cccccccc}
\hline & $\begin{array}{c}\text { X1. Co- } \\
\text { Creation }\end{array}$ & $\begin{array}{c}\text { X2. } \\
\text { Currency }\end{array}$ & $\begin{array}{c}\text { X3. Communal } \\
\text { activity }\end{array}$ & $\begin{array}{c}\text { X4. } \\
\text { Conversation }\end{array}$ & $\begin{array}{c}\text { X5. Halal } \\
\text { Awareness }\end{array}$ & $\begin{array}{c}\text { X6.Reference } \\
\text { Group }\end{array}$ & $\begin{array}{c}\text { Y.Purchase } \\
\text { Behavior }\end{array}$ \\
\hline X1.2 & $\mathbf{0 . 5 6 5}$ & 0.246 & 0.220 & 0.254 & 0.032 & 0.023 & 0.210 \\
X1.3 & 0.856 & 0.375 & 0.100 & 0.531 & 0.261 & 0.065 & 0.588 \\
X1.5 & 0.811 & 0.519 & 0.188 & 0.481 & 0.285 & 0.131 & 0.514 \\
X2.1 & 0.381 & 0.791 & 0.114 & 0.340 & 0.330 & 0.192 & 0.380 \\
X2.3 & 0.460 & 0.836 & 0.236 & 0.439 & 0.232 & 0.181 & 0.424 \\
X3.1 & 0.194 & 0.219 & 1.000 & 0.096 & 0.127 & 0.026 & 0.228 \\
X4.2 & 0.551 & 0.508 & 0.112 & 0.891 & 0.440 & 0.175 & 0.579 \\
\hline
\end{tabular}




\section{J O U R N A L O F \\ CONSUMER SCIENCES}

Table 6. Cross loading value (cont..)

\begin{tabular}{lccccccc}
\hline & $\begin{array}{c}\text { X1. Co- } \\
\text { Creation }\end{array}$ & $\begin{array}{c}\text { X2. } \\
\text { Currency }\end{array}$ & $\begin{array}{c}\text { X3. Communal } \\
\text { activity }\end{array}$ & $\begin{array}{c}\text { X4. } \\
\text { Conversation }\end{array}$ & $\begin{array}{c}\text { X5.Halal } \\
\text { Awareness }\end{array}$ & $\begin{array}{c}\text { X6.Reference } \\
\text { Group }\end{array}$ & $\begin{array}{c}\text { Y.Purchase } \\
\text { Behavior }\end{array}$ \\
\hline $\mathrm{X} 4.4$ & 0.471 & 0.315 & 0.051 & 0.848 & 0.201 & 0.133 & 0.496 \\
$\mathrm{X} 5.1$ & 0.328 & 0.383 & 0.120 & 0.387 & 0.868 & 0.098 & 0.458 \\
$\mathrm{X} 5.3$ & 0.143 & 0.227 & 0.020 & 0.196 & 0.820 & 0.077 & 0.266 \\
$\mathrm{X} 5.4$ & 0.218 & 0.199 & 0.156 & 0.318 & 0.811 & 0.004 & 0.333 \\
$\mathrm{X} 6.2$ & 0.106 & 0.228 & 0.026 & 0.179 & 0.075 & 1.000 & 0.229 \\
$\mathrm{Y} 1$ & 0.584 & 0.441 & 0.185 & 0.569 & 0.366 & 0.257 & 0.872 \\
$\mathrm{Y} 4$ & 0.474 & 0.393 & 0.202 & 0.474 & 0.384 & 0.120 & 0.818 \\
\hline
\end{tabular}

\subsection{Measurement Model Fit During Pandemic}

Similarly, at the stage of the compatibility test of the measurement model in conditions before the Covid-19 pandemic, during the pandemic, this test was also carried out by testing the validity and reliability of the outer model so that it had the accuracy and reliability of the questionnaire data used in the study. The analysis of the outer model reflects the relationship between latent variables and their indicators. The value that relates the latent variable to the indicator is called the loading factor, which tests the validity. Figure 4 is a measurement model obtained after several iterations. In this outer model, the loading factor has been more than 0.5 to enter the valid criteria (convergent validity). Besides that, the AVE value has also met the criteria of more than 0.5 , so it is also said to be valid.

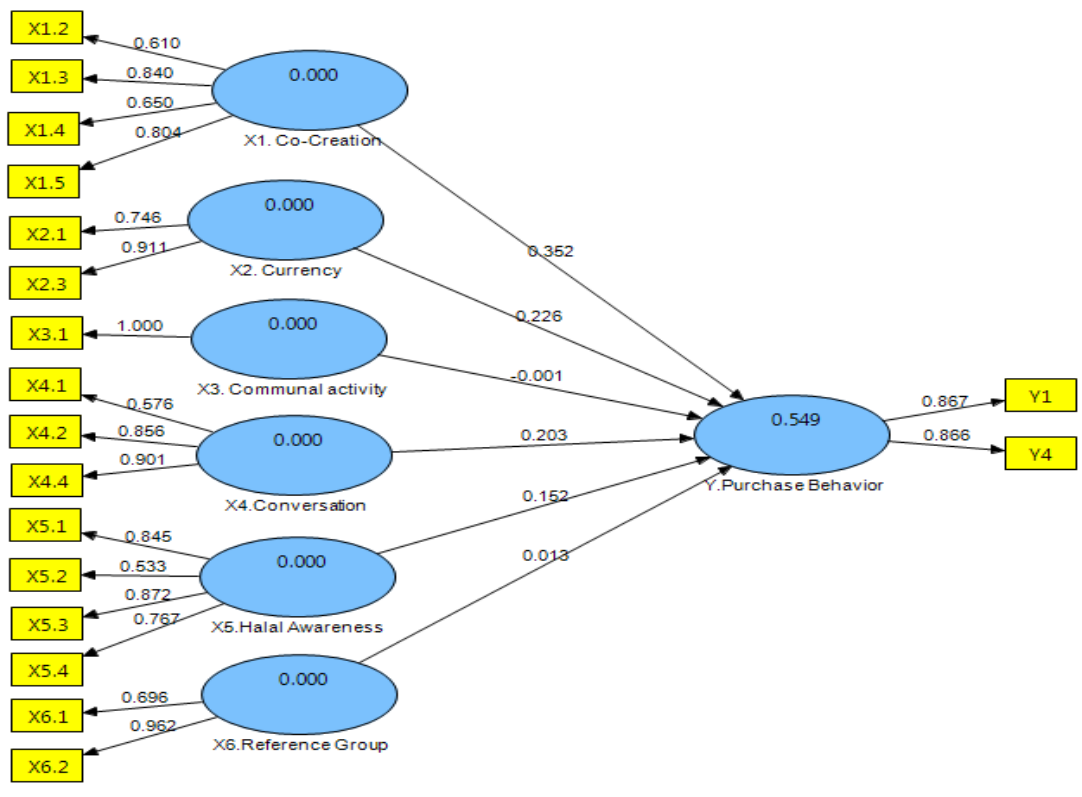

Figure 4. Loading factor during the pandemic

The results in Table 7 also show that the AVE value of each latent variable is more than 0.5 points, or in other words, each variable is greater than the correlation that occurs, so that it meets the requirements of convergent validity, which indicates the questionnaire is good. 
Table 7. Average Variance Extracted (AVE) and Composite Reliability

\begin{tabular}{lrr}
\hline & AVE & Composite Reliability \\
\hline X1. Co-Creation & 0.537 & 0.820 \\
X2. Currency & 0.693 & 0.818 \\
X3. Communal activity & 1.000 & 1.000 \\
X4. Conversation & 0.625 & 0.829 \\
X5. Halal Awareness & 0.587 & 0.846 \\
X6. Reference Group & 0.706 & 0.824 \\
Y. Purchase Behavior & 0.751 & 0.858 \\
\hline
\end{tabular}

Table 7 also shows that the latent variables used in this study have a good level of reliability, with the value of each latent variable being more than 0.7 . While in table 8 , the overall value of cross loading between indicators for latent variables is greater than other latent variables, so it is included in the discriminant validity category, which shows that the discriminant validity of each indicator has been fulfilled for the variable.

Table 8. Cross Loading Value

\begin{tabular}{lcrrrrrr}
\hline & $\begin{array}{c}\text { X1. Co- } \\
\text { Creation }\end{array}$ & X2. Currency & $\begin{array}{c}\text { X3. Communal } \\
\text { activity }\end{array}$ & $\begin{array}{c}\text { X4. } \\
\text { Conversation }\end{array}$ & $\begin{array}{c}\text { X5. Halal } \\
\text { Awareness }\end{array}$ & $\begin{array}{c}\text { X6.Reference } \\
\text { Group }\end{array}$ & $\begin{array}{c}\text { Y.Purchase } \\
\text { Behavior }\end{array}$ \\
\hline X1.2 & 0.610 & 0.094 & 0.067 & 0.493 & 0.136 & 0.118 & 0.305 \\
X1.3 & 0.840 & 0.417 & 0.201 & 0.684 & 0.328 & 0.005 & 0.576 \\
X1.4 & 0.650 & 0.157 & 0.233 & 0.455 & 0.355 & -0.014 & 0.449 \\
X1.5 & 0.804 & 0.445 & 0.255 & 0.609 & 0.320 & 0.019 & 0.558 \\
X2.1 & 0.266 & 0.746 & 0.140 & 0.272 & 0.277 & 0.198 & 0.314 \\
X2.3 & 0.407 & 0.911 & 0.385 & 0.428 & 0.259 & 0.202 & 0.508 \\
X3.1 & 0.271 & 0.344 & 1.000 & 0.130 & 0.144 & 0.221 & 0.223 \\
X4.1 & 0.553 & 0.119 & -0.009 & 0.576 & 0.283 & -0.035 & 0.342 \\
X4.2 & 0.575 & 0.383 & 0.127 & 0.856 & 0.354 & 0.119 & 0.511 \\
X4.4 & 0.706 & 0.455 & 0.150 & 0.901 & 0.357 & 0.118 & 0.618 \\
X5.1 & 0.369 & 0.394 & 0.184 & 0.456 & 0.845 & 0.048 & 0.470 \\
X5.2 & 0.374 & 0.108 & 0.096 & 0.222 & 0.533 & -0.044 & 0.238 \\
X5.3 & 0.257 & 0.215 & 0.083 & 0.296 & 0.872 & -0.004 & 0.349 \\
X5.4 & 0.231 & 0.128 & 0.029 & 0.218 & 0.767 & -0.150 & 0.230 \\
X6.1 & -0.024 & 0.128 & 0.280 & -0.001 & -0.066 & 0.696 & 0.038 \\
X6.2 & 0.047 & 0.242 & 0.165 & 0.126 & -0.004 & 0.962 & 0.101 \\
Y1 & 0.568 & 0.403 & 0.168 & 0.630 & 0.390 & 0.084 & 0.867 \\
Y4 & 0.585 & 0.484 & 0.219 & 0.476 & 0.390 & 0.079 & 0.866 \\
\hline
\end{tabular}

\subsection{Structural Model Fit Before and During Pandemic}

Bootstrapping results in Table 9 show that co-creation $(\mathrm{H} 1)$, communal activity $(\mathrm{H} 3)$, conversation (H4), halal awareness ( $\mathrm{H} 5)$, and reference group (H6) have a significant influence on purchase behavior with a t-statistical value $>t$-table (1.96) at a significant level of $5 \%$. However, currency $(\mathrm{H} 2)$ does not have a significant effect on purchase behavior with a t-statistic value of $1.493<\mathrm{t}$-table $(1.96)$ at a significant level of $5 \%$. Therefore, the purchase behavior structural model produces an R-Square value of $55.6 \%$, which means that the diversity of Purchase behavior before the Covid19 pandemic that the model can explain is $55.6 \%$, while other factors outside the model explain the remaining $44.4 \%$. 
Table 9. Path Coefficient and T-Statistic the influence between latent variables before the Covid-19 pandemic

\begin{tabular}{lrrr}
\hline & Path Coefficient & T-statistic & R-square \\
\hline X1. Co-Creation -> Y.Purchase Behavior & 0.339 & $6.536^{*}$ & \\
X2. Currency -> Y.Purchase Behavior & 0.071 & $1.493^{\mathrm{ns}}$ & \\
X3. Communal activity -> Y.Purchase Behavior & 0.092 & $2.365^{*}$ & \\
X4. Conversation -> Y.Purchase Behavior & 0.286 & $6.014^{*}$ & 0.556 \\
X5. Halal awareness -> Y.Purchase Behavior & 0.190 & $5.072^{*}$ & \\
X6. Reference Group -> Y.Purchase Behavior & 0.109 & $2.403^{*}$ & \\
\hline
\end{tabular}

* significant at $\mathrm{p}<0.05$; ns : not significant

Bootstrapping results in Table 10 show that co-creation $(\mathrm{H} 1)$, currency $(\mathrm{H} 2)$, conversation ( $\mathrm{H} 4)$, and halal awareness ( $\mathrm{H} 5)$ have a significant influence on purchase behavior with a t-statistical value > t-table (1.96) at a significant level of $5 \%$. However, communal activity $(\mathrm{H} 2)$ and reference group $(\mathrm{H} 6)$ do not have a significant effect on purchase behavior, with a value oft-statistic < t-table (1.96) at a 5\% significance level. The purchase behavior structural model produces an $r$-square value of $54.9 \%$, which means that the diversity of purchase behavior during the covid-19 pandemic that the model can explain is $54.9 \%$, while other factors outside the model explain the remaining $44.1 \%$.

Table 10. Path Coefficient and T-Statistic the influence between latent variables during Covid-19 pandemic

\begin{tabular}{lrrr}
\hline & Path Coefficient & T Statistik & R-square \\
\hline X1. Co-Creation -> Y.Purchase Behavior & 0.352 & $4.531^{*}$ & \\
X2. Currency -> Y.Purchase Behavior & 0.226 & $4.573^{*}$ & \\
X3. Communal activity -> Y.Purchase Behavior & -0.001 & $0.065^{\text {tn }}$ & 0.549 \\
X4. Conversation -> Y.Purchase Behavior & 0.203 & $3.524^{*}$ & \\
X5. Halal awareness -> Y.Purchase Behavior & 0.152 & $2.899^{*}$ & \\
X6. Reference Group -> Y.Purchase Behavior & 0.013 & $0.506^{\mathrm{tn}}$ & \\
\hline
\end{tabular}

\subsection{Goodness of Fit (GOF) Test Before and During Pandemic}

The Goodness-of-fit (GOF) test validates the overall model, better known as the GOF index. This index was developed to evaluate measurement models and structural models, and besides that, it also provides a simple measurement for the overall model prediction and is shown in Table 11 and 12, by entering into the GOF formula, the GOF value before the Covid-19 pandemic was 0.655 (Table 11). This means that the GOF value has exceeded 0.36 so that it is included in the large category. This condition indicates that the research model can explain the diversity of research data by $65 \%$.

Table 11. GOF before pandemic

\begin{tabular}{|c|c|c|c|c|c|c|c|}
\hline & & AVE & Composite & $\begin{array}{c}\mathrm{R} \\
\text { Square }\end{array}$ & $\begin{array}{c}\text { Cronbachs } \\
\text { Alpha }\end{array}$ & Communal & Redundancy \\
\hline $\mathrm{X} 1$ & Co-Creation & 0.569 & 0.794 & & 0.642 & 0.569 & \\
\hline $\mathrm{X} 2$ & Currency & 0.662 & 0.797 & & 0.491 & 0.662 & \\
\hline $\mathrm{X} 3$ & $\begin{array}{l}\text { Communal } \\
\text { Activity }\end{array}$ & 1 & 1 & & 1 & 1 & \\
\hline $\mathrm{X} 4$ & Conversation & 0.756 & 0.861 & & 0.679 & 0.756 & \\
\hline X5 & $\begin{array}{l}\text { Halal } \\
\text { Awareness }\end{array}$ & 0.694 & 0.872 & & 0.787 & 0.694 & \\
\hline$X 6$ & $\begin{array}{l}\text { Reference } \\
\text { Group }\end{array}$ & 1 & 1 & & 1 & 1 & \\
\hline $\mathrm{Y}$ & $\begin{array}{l}\text { Purchase } \\
\text { Behavior }\end{array}$ & 0.714 & 0.833 & 0.556 & 0.602 & 0.714 & 0.222 \\
\hline
\end{tabular}

In addition to conditions before the pandemic, GOF measurements were also carried out for conditions. This ensures that the model during the pandemic is valid and suitable for use in research, as reflected in Table 12. The GOF value during the Covid19 pandemic was 0.620 . This means that the research model's diversity of research data can be explained by $62 \%$ and is in a large category. 
Table 12. GOF during pandemic

\begin{tabular}{|c|c|c|c|c|c|c|c|}
\hline & & AVE & Composite & $\begin{array}{c}\mathrm{R} \\
\text { Square }\end{array}$ & $\begin{array}{c}\text { Cronbachs } \\
\text { Alpha }\end{array}$ & Communal & Redundancy \\
\hline $\mathrm{X} 1$ & Co-Creation & 0.537 & 0.820 & & 0.713 & 0.537 & \\
\hline $\mathrm{X} 2$ & Currency & 0.693 & 0.818 & & 0.577 & 0.693 & \\
\hline $\mathrm{X} 3$ & $\begin{array}{l}\text { Communal } \\
\text { Activity }\end{array}$ & 1 & 1 & & 1 & 1 & \\
\hline X4 & Conversation & 0.625 & 0.829 & & 0.689 & 0.625 & \\
\hline X5 & Halal Awareness & 0.587 & 0.846 & & 0.763 & 0.587 & \\
\hline X6 & $\begin{array}{l}\text { Reference } \\
\text { Group }\end{array}$ & 0.706 & 0.824 & & 0.644 & 0.706 & \\
\hline $\mathrm{Y}$ & $\begin{array}{l}\text { Purchase } \\
\text { Behavior }\end{array}$ & 0.751 & 0.858 & 0.549 & 0.669 & 0.751 & 0.258 \\
\hline
\end{tabular}

\section{Discussions}

This study aims to analyze the determinants of purchasing behavior for facial serum cosmetic products in conditions before and during the Covid-19 pandemic. There are differences in the variables that influence the buying behavior of facial serum cosmetics, namely before the pandemic, all components of the marketing mix $4 \mathrm{C}$ affect purchasing behavior, except for the currency variable, which has no significant effect on purchasing behavior, meaning that respondents do not mind the price of facial serum, and focus on benefits, but during pandemic circumstances are different. This is driven by the increasingly critical consumer in choosing a product and highly considers the factor of price suitability with the benefits obtained to achieve a certain level of satisfaction (Mustaqimah, Hartoyo, \& Nurmalina, 2019). In addition, there are also more and more local brand products that offer various facial care ingredients at low prices (SWA, 2021). In a pandemic situation, the communal activation variable does not affect the buying behavior of facial serum. This is because consumers focus on the benefits, prices, and promotional patterns offered by producers so that by switching to online shopping supported by adequate logistical support, consumers are not worried about distribution channels (Türk, 2019). In other words, the $4 C$ marketing mix concept is still relevant to be used as a benchmark in knowing the factors that influence buying behavior (Chelliah, Chin, Annamala, \& Munusamy, 2013).

In the halal awareness variable, both before the Covid-19 pandemic and during the pandemic, both affect the purchasing behavior of facial serum cosmetic products. Religious beliefs held by the majority of the population, health reasons, and the halal logo increase awareness of the halalness of a consumed product (Ambali \& Bakar, 2014). However, in practice, the process of obtaining halal certification requires a lot of effort (Hasan, Sulong, \& Tanakinjal, 2020). Although halal certification sometimes becomes a trend and makes a product more competitive.

There are significant differences between reference group variables before and during the Covid-19 pandemic. Changes in public consumption patterns and the consumer confidence index (an indicator showing consumer optimism or pessimism about economic conditions) decreased dramatically during the Covid-19 pandemic. This includes trust in reference groups. Consumers prioritize the basic needs of life over other needs. Consumers limit spending due to a decrease in income so that their purchasing power decreases and they do not buy beyond their needs (Hartatin \& Simanjuntak, 2016). In addition, reference groups, especially influencers on social media, do not necessarily influence buying behavior (Hermanda, Sumarwan, \& Tinaprilla, 2019).

Based on the study results, several factors influence purchase behavior: the $4 \mathrm{C}$ marketing mix (co-creation, currency, communal activation, conversation), Halal awareness, and reference group. However, the path coefficient value between the variables on the purchasing behavior of facial serum cosmetic products is the highest both for conditions before the Covid-19 pandemic and during the pandemic, namely the co-creation and conversation variables. This situation shows that business people in the marketing 4.0 era for facial serum cosmetic products should focus on the $4 \mathrm{C}$ marketing mix by prioritizing co-creation and conversation strategies. Furthermore, 
in increasing sales and capturing niches or market segments, business people need to explore what potential customers need and want and involve customers at the ideation stage or concept determination and product innovation. This can be done by conducting consumer surveys regarding products in demand, including serum content, ingredients used, and interest packaging. In addition, business people need to establish good communication considering that communication is now more accessible with various social media, virtual chat, and online consultations. Therefore, it is easy for consumers to submit criticisms and product suggestions. This is very useful for increasing consumer loyalty and giving a positive impression to existing and potential new customers.

This research is limited to questionnaire distribution, which is only through google forms distributed through social networks. Therefore, it is prone to miscommunication between respondents and researchers regarding the contents of the questionnaire. This situation had to be carried out considering the conditions that made it impossible to collect data directly or face to face because of the Covid-19 pandemic.

\section{Conclusions}

Based on the study results, both before and during the covid-19 pandemic, consumers who are dominant in purchasing facial serum cosmetic products are in the age range of 31-40 years are Muslim. In terms of ethnicity, it is dominated by Javanese and Sundanese with a D3/S1 education level. For the income level, $33 \%$ are respondents with an income level of 5.000 .000 to 10.000 .000 where the dominant level of expenditure is above 5.000 .000 .

Marketing mix $4 \mathrm{C}$ (co-creation, currency, communal activation, conversation), Halal awareness, and reference group influence the buying behavior of local facial serum cosmetic products. In conditions before the Covid-19 pandemic, the only currency did not significantly affect buying behavior. In addition, unlike during the Covid-19 pandemic, communal activation and reference groups did not significantly affect purchasing behavior.

The managerial implication offered is that business actors focus on co-creation and conversation to increase sales, capture niches or market segments, increase consumer loyalty, and positively impact existing and potential new customers.

\section{Recommendation}

The industry is advised to use the $4 \mathrm{C}$ marketing mix in evaluating sales. This research also looks at consumer buying behavior patterns in conditions before and during the Covid-19 pandemic for regulators or policy-makers. Suggested further research is with additional variables, namely for the consumer satisfaction variable on the behavior of purchasing cosmetic products both for conditions before the Covid-19 pandemic, during the pandemic, and after the pandemic is declared over so that it can be compared more comprehensively.

\section{Citation information}

Cite this article as Farisha, M., Hartoyo, \& Safari, A. (2022). Does covid-19 pandemic change the consumer purchase behavior towards cosmetic products?. Journal of Consumer Sciences, 7(1), 1-19. doi: https://doi.org/10.29244/jcs.7.1.119

\section{References}

Abdulrani, N. S., \& Sarojani D. K. (2018). Factors that influence Malay students in purchasing skin care products in Malaysia. Journal of Business and Retail Management Research, 13(1), 1521. doi:10.2405/JBRMR/V13IS01/ART-2

Ajzen, I. (1991). The theory of planned behavior in organizational behavior and human decision 


\section{J O U R N A L O F CONSUMER SCIENCES}

processes. Theories of Cognitive Self-Regulation, 50(2), 179-211. doi:

https://doi.org/10.1016/07495978(91)90020-T

Ambali, A. R., \& Bakar, A. N. (2014). People's awareness on halal foods and products: potential issues for policy-makers. Procedia-Social and Behavioral Sciences, 121, 3-25. doi:10.1016/j.sbspro.2014.01.1104

Annabi C. A., \& Ibidapo-Obe 0. 0. (2017). Halal certification organizations in the united kingdom: an exploration of halal cosmetic certification. Journal of Islamic Marketing, 8(1), 107-126. doi: 10.1108/JIMA-06-2015-0045.

Ayyub, R. M. (2015). Exploring perceptions of non-muslims toward halal foods in the UK. British Food Journal, 117(9), 2328-2343. doi: 10.1108/BFJ-07-2014-0257.

Aziz, Y. A., \& Chok N. V. (2013). The role of halal awareness, halal certification, and marketing components in determining halal purchase intention among nonmuslims in Malaysia: a structural equation modeling. Journal of International Food \& Agribusiness Marketing, 25(1), 1-23. doi: 10.1080/08974438.2013.723997.

Bearden, W. O., \& Etzel, M. J. (1982). Reference group influence on product and brand purchase decision. Journal of Consumer Research. 9(2), 183-194. doi:10.1086/208911.

Chelliah, S., Chin, K. K, Annamalah, S., \& Munusamy J. (2013). Does the marketing mix still relevant? a study on herbal coffee in Malaysia. International Journal of Management and Innovation, 5(1), 31-45.

Chinomona, R., \& Maziriri, E. T. (2017). The influence of brand awareness, brand association and product quality on brand loyalty and repurchase intention: a case of male consumers for cosmetic brand in South Africa. Journal of Business and Retail Management Research, 12(1), 143-154. doi: 10.24052/jbrmr/v12is01/tiobabaap qoblariacomcfcbisa.

Cohen, J. (1988). Statistical power analysis for the behavioral sciences, $2^{\text {nd }}$ edition. New Jersey: Lawrence Earlbaum Associates.
Effendi, I. (2019). Analisis preferensi dan keputusan pembelian konsumen buah pada generasi $Y$ (kasus ritel modern dan ritel tradisional Kota Bogor) (Theses). Institut Pertanian Bogor, Bogor, Indonesia

Eganeal, P. Q., Tarigan, J. W. Z., Br. Sitepu, R., \& Kumar, S. S. (2020). The impact of marketing mix on the consumer purchase decision in the Surabaya-Indonesia hotel residence. SHS Web of Conferences, 76(1), 01038. doi: $10.1051 /$ shsconf/2020761038.

Elasrag, H. (2016). Halal industry: key challenges and opportunities. SSRN Electronic Journal, 1-33. doi:10.2139//ssrn.2735417.

Ghozali, I., \& Latan H. (2012). Partial Least Square: SmartPLS $2.0 \mathrm{M3}$ concepts, techniques and applications (Partial Least Square: konsep, teknik, dan aplikasi SmartPLS 2.0 M3). Semarang: Badan Penerbit Universitas Diponegoro.

Gong, Y., Hou W., Zhang Q., \& Tian S. (2018). Discount or gift? not just to save money. Journal of Contemporary Marketing Science, 1(1), 53-75. doi: $10.1108 /$ jcmars08-2018-0009.

Hair, J. F. (2006). Multivariate Data Analysis, 6th Edition (Analisis Data Multivariate, Edisi ke-6). New Jersey: Prentice-Hall.

Hall, A., \& Tower N. (2017). Understanding how millennial shoppers decide what to buy: digitally connected unseen journeys. International Journal of Retail \& Distribution Management, 45(5), 498-517. doi: 10.1108/IJRDM-11-2016-0206.

Haque, A., Sarwar A., Yasmin F., Tarofder A. K., \& Hossain M. A. (2015). Non-muslim consumers' perception toward purchasing halal food products in Malaysia. Journal of Islamic Marketing, 6(1), 133147. doi: 10.1108/JIMA-04-20140033.

Hartatin, D., \& Simanjuntak, M. (2016). The effect of value and reference group on young consumer's hedonic buying. Journal of Consumer Sciences, 1(1), 33-46. doi: https://doi.org/10.29244/jcs.1.1. 33-46 


\section{J O U R N A L O F CONSUMER SCIENCES}

Hasan, H., Sulong R. S., \& Tanakinjal G. H. (2020). Halal certification among SMEs in Kota Kinabalu, Sabah. Journal of Consumer Sciences, 5(1), 16-28. doi: https://doi.org/10.29244/jcs.5.1. 16-28

Hermanda, A., Sumarwan U., \& Tinaprilla N. (2019). The effect of social media influencers on brand image, self-contact, and purchase intention. Journal of Consumer Sciences, 4(2), 76-89. Doi: https://doi.org/10.29244/jcs.4.2. 76-89.

Hutauruk, M.R. (2020). Applicability of the $4 C$ marketing mix to consumer's decision to select outdoor cafes moderated by consumer behavior in the covid pandemic situation (Penerapan bauran pemasaran $4 \mathrm{C}$ terhadap keputusan konsumen untuk memilih kafe outdoor dimoderatori oleh perilaku konsumen dalam situasi pandemi covid). Jurnal Riset Inossa, 2(2), 80-91.

Ishak, S., Che Oemar A. R., Khalid K., Intan I. S., \& Hussain M. Y. (2020). Cosmetics purchase behavior of educated millennials Muslim females. Journal of Islamic Marketing, 11(5), 1055-1071. doi: 10.1108/JIMA-01-2019-0014.

Kandemir, G., Pirtini S., \& Bayraktar A. (2019). A research on the role of consumer involvement and product knowledge levels on purchasing decisions. Turkish Journal of Marketing, 4(2), 162 183. doi: $10.30685 /$ tujom.v4i2.57.

[Kemenperin] Kementerian Perindustrian. (2019). More and more shiny, the national cosmetic industry grows by 20 percent (Kian kinclong, industri kosmetik nasional tumbuh 20 persen). Jakarta: Kemenperin.

Kotler, P., \& Keller, K.L. (2008). Marketing Management 13th Edition. New Jersey: Pearson Prentice Hall.

Kotler, P., Kartajaya, H., \& Setiawan, I. (2017). Marketing 4.0 is Moving from Traditional to Digital (Marketing 4.0 Bergerak dari Tradisional ke Digital). Jakarta: Gramedia.

Krisnawati, D. (2019). The effect of co-creation, currency, communal activity, and conversation on the consumer journey (Pengaruh co- creation, currency, communal activity dan conversation terhadap consumer journey). Jurnal Ekonomi dan Industri, 20(2), 1-11. doi:

http://dx.doi.org/10.35137/jei.v2 $0 \mathrm{i} 2.310$

Kurniawati, D. A., \& Savitri, H. (2019). Awareness level analysis of Indonesian consumers toward the halal product. Journal of Islamic Marketing, 11(2), 531-546. doi: 10.119=08/ JIMA-10-2017-0104.

Mican, D., \& Sitartaut, D. A. (2020). Analysis of the factors impacting the online shopping decisionmaking process. Studia Universitatis Babes-Bolyai Oeconomica, 65(1), 54-66. doi: 10.2478/subboeco-2020-0004.

Mustaqimah, A., Hartoyo, H., \& Nurmalina, R. (2019). Marketing mix effect towards customer satisfaction and loyalty: a case study of rejuve cold-pressed drinks. Indonesian Journal of Business and Entrepreneurship, 5(3), 310-320. doi: 10.17358/ijbe.5.3.310.

Mutmainah, L. (2018). The role of religiosity, halal awareness, halal certification, and food ingredients on purchase intention of halal food. Journal of Islamic Economics, Finance, and Banking, 1(1), 33-50. doi: 10.12928/ijiefb.v1i1.284.

Nurhayati, T., \& Hendar H. (2019). Personal intrinsic religiosity and product knowledge on halal product purchase intention: role of halal product awareness. Journal of Islamic Marketing, 11(3), 603620. doi: 10.1108/JIMA-11-20180220.

Pandowo, M., \& Tuwo H. J. (2015). The influence of social factors on customer purchase intention in using wedding organizer in Manado (Pengaruh faktor sosial terhadap niat beli konsumen dalam menggunakan wedding organizer di Manado). Jurnal Riset Ekonomi, Manajemen, Bisnis dan Akuntansi, 3(3), 29-38. doi: 1035794/emba.v3i3.9308.

Ramadhan, A. F., \& Simanjuntak, M. (2018). Perilaku pembelian hedonis generasi Z (Generation Z hedonic buying behavior). Jurnal IImu Keluarga dan Konsumen, 11(3), 243-254. doi: 
https://doi.org/10.24156/jikk.201

8.11.3.243

Rezai, G., Mohamed, Z., \&

Shamsudin, M. N. (2012). Nonmuslim consumers' understanding of halal principle in Malaysia.

Journal of Islamic Marketing, 3(1), 35-46. doi:

10.1108/17590831211206572.

Rieg, D. L., Scramim, F. C. L., Paola, E., \& Rugfino, F. A. (2018). The influence of the seller's performance on the consumer purchase of clothes and personal care, toiletries, and cosmetics products. Independent Journal of Management \& Production, 9(2), 507-525. doi:

10.14807/ijmp.v9i2.713.

Salem, M. Z. (2018). Effects of perfume packaging on basque female consumers purchase decision in Spain. Emerald Publishing Limited, Management Decision, 56(8), 1748-1768. doi: 10.1108/MD-04-2017-0363.

Setyaningsih, E. D., \& Marwansyah, S. (2019). The effect of halal certification and awareness through an interest in buying halal food products. Syi'ar Istishadi Journal of Islamic Economics, Finance, and Banking, 3(1), 64-79. doi: $10.35448 /$ jiec.v3il.5515.

Schiffman, L. G., \& Wisenblit, J. (2019). Consumer Behavior 12th Edition. New Jersey: Pearson Prentice Hall.

Sumarwan, U. (2010). Consumer Behavior Theory and Its Application in Marketing (Perilaku Konsumen Teori dan Penerapannya dalam Pemasaran). Bogor: Ghalia Indonesia.

Sunyoto, D. (2013). Consumer Behavior (Perilaku konsumen). Yogyakarta: CAPS.

SWA. (2021). Produk kecantikan lokal diminati konsumen (Produk kecantikan lokal semakin diminati konsumen). Retrieved from swaonline:

https://swa.co.id/swa/trends/pro duk-kecantikan-lokal-semakindiminati-konsumen

Türk, E. (2019). Factors affecting online shopping decision: customers in Turkey. Journal of International Trade, Logistics, and Law, 5(1), 35-43. ISSN 2149-9748 